\title{
(5)
}

\author{
Al-Dzikra: Jurnal Studi Ilmu al-Qur'an dan al-Hadits \\ P-ISSN: 1978-0893, E-ISSN: 2714-7916 \\ http://ejournal.radenintan.ac.id/index.php/al-dzikra \\ Volume 14, No. 2, Desember Tahun 2020, Halaman 271 - 292 \\ DOI: $10.24042 /$ al-dzikra.v14i2.6578
}

\section{Memahami Hadits Kepemimpinan Dari Bangsa Quraisy dan Relevansinya Dengan Konsep Kepemimpinan Kontemporer}

\author{
Imam Mustofa \\ Institut Agama Islam Negeri (IAIN) Metro \\ mustofaiain@metrouniv.ac.id
}

\begin{tabular}{l|l|l}
\hline Received: 11-06-2020 & Revised: 01-12-2020 & Accepted: 07-12-2020 \\
\hline
\end{tabular}

\begin{abstract}
This paper examines the contextualization of the understanding of hadiths related to the leadership of the Quraysh tribe, where a problem arises how this hadith text intersects with the sociological and socio-cultural realities of modern society today and Islam has spread throughout the world and each country has already spread. Building and agreeing on a leadership system. This study is a normative literature study where the data comes from literature, books, books and articles related to the hadith study. Sources or studies of references are analyzed with content analysis using language, hadith, history and sociological approaches. Based on this study, the author can conclude that the hadith about the leadership of the Quraysh tribe textually states that the leadership of the Quraysh, however, needs a contextual understanding of the spirit and substance of the hadiths about the leadership of the Quraysh tribe that must be practiced and continue to carry out maqas syari 'ah ah that is in it such as justice, truth, and protection.
\end{abstract}




\section{Abstrak}

Tulisan ini mengkaji kontekstualisasi pemahaman hadits-hadits yang terkait dengan kepemimpinan dari suku Quraisy, dimana muncul sebuah persoalan bagaimana teks hadits ini bersinggungan dengan realitas sosiologis dan sosi-kultur masyarakat modern saat ini dan Islam sudah menyebar ke seluruh penjuru dunia dan masing-masing negara sudah membangun dan menyepakati sistem kepemimpinan. Kajian ini merupakan kajian normatif kepustakaan dimana datanya berasal dari literatur, kitab, buku dan artikel yang berkaitan dengan kajian hadits tersebut. Sumber atau kajian dari referensi-refrensi dianalisa dengan analisa konten menggunakan pendekatan bahasa, ilmu hadits, sejarah dan sosiologis. Berdasarkan kajian tersebut, penulis dapat menyimpulkan bahwa hadits tentang kepemimpinan dari suku Quraisy secara tekstual memang menyatakan bahwa kepemimpinan dari kaum Quraisy, akan tetapi perlu pemahaman secara kontekstual dengan spirit dan substansi hadits-hadits tentang kepemimpinan dari suku Quraisy harus diamalkan serta tetap menjalankan maqașid syarì 'ah yang ada didalamnya seperti keadilan, kebenaran, dan pengayoman.

Kata Kunci: Al-Aimmah; Kontekstualisasi Pemahaman Hadits; Qurasy.

\section{A. Pendahuluan}

Kepemimpinan merupakan masalah yang sangat urgen, baik ditinjau dari sisi normatif berdasarkan ajaran Islam maupun dalam perspektif sosiologis. Secara normatif kepemimpinan mempunyai landasan yang jelas, baik dari al-Qur'an maupun dari al-Sunnah. ${ }^{1}$ Secara sosiologis, hal ini sudah menjadi "kesepakatan" dalam masyarakat, bahwa untuk menciptakan ketertiban dan keteraturan harus ada pemimpin dan sistem kepemimpinan. $^{2}$

Hadits kepemimpinan dari kaum Quraisy secara tekstual memang jelas berbunyi demikian (الأئمة من قريش). Quraisy

${ }^{1}$ Ahmadie Thoha, penerj.,Muqaddimah Ibn Khaldun (Jakarta: Pustaka Firdaus, 2000), hlm. 187-395.

${ }^{2}$ Baca Jürgen Meffert dan Anand Swaminathan, "Leadership And The Urgency For Digital Transformation," Leader to Leader 2018, no. 88 (Maret 2018): hlm. 44-49, https://doi.org/10.1002/ltl.20357; Baca juga DK Pub, Leadership: Inspiring, Empowering, Supporting (DK Pub, 2015). 
merupakan anak keturunan Nadar bin Kinanah. Ada perbedaan pendapat ulama mengenai penyebutan mereka dengan sebutan "Quraisy". Pendapat lain mengatakan bahwa Quraisy berasal dari kata al-Qarsy yang memiliki arti berusaha dan mengumpulkan. Kaum Quraisy termasuk golongan suku Mudar cikal bakal dan paling perkasa dibanding suku Mudar lainnya. ${ }^{3}$ Quraisy menjadi nama suku yang sangat terkenal di Makkah dan menjadi penjaga Kabah sebagai bangunan suci tempat berkumpulnya para dewa dan pusat ibadah orang-orang Arab. ${ }^{4}$ Suku ini juga mempunyai koneksi yang luas dan sudah melakukan perjalanan yang jauh untuk berdagang. ${ }^{5}$ Maka sangat wajar ia menjadi suku yang sangat istimewa saat itu.

Persoalan yang muncul adalah disaat masalah kepemimpinan dalam doktrin dan teks-teks al-Qur'an dan alSunnah bersinggungan dengan realitas sosiologis dan sosio-kultur masyarakat saat ini. Terlebih bersinggungan dengan konsep kepemimpinan dalam sistem negara dan masyarakat modern. Salah satu masalah ini adalah tentang adanya teks hadits yang menyatakan bahwa kepemimpinan merupakan hak suku Qurasy tersebut yang notabene merupakan salah satu suku besar dan ternama di Kota Makkah yang saat ini merupakan bagian dari Saudi Arabia.

Sebagai bagian dari sumber ajaran Islam, maka hadits ini tidak bisa dikatakan tidak berlaku, karena hal ini tentu akan bertentangan dengan adagium bahwa ajaran Islam șāliḥun li kulli zamān wa makān. Di sinilah pentingnya pemahaman hadits tersebut secara komprehansif, baik dari sisi teks maupun konteks, terlebih konteks Indonesia. Karena bagaimana pun, sebagai sumber syariat Islam, hadits atau al-Sunnah harus tetap diamalkan, terlebih terkait dengan masalah kepemimpinan. Lalu bagaimana implementasi dan aktualisasi hadits tersebut di tengah-tengah kehidupan modern dengan adanya sistem negara yang sudah tarbagi-bagi baik secara wilayah dan administrasi. Hal

${ }^{3}$ Thoha, Muqaddimah Ibn Khaldun, hlm. 241.

${ }^{4}$ Philip Khuri Hitti, History of the Arabs (Jakarta: Serambi Ilmu Semesta, 2005), hlm. 142.

5 Safiy al-Rahman al-Mubarakfuri, "al-Rahiq al-Makhtum" (Riyad: Makhtabah Dar al-Salam, 1994), hlm. 60. 
ini bukanlah masalah sepele, mengingat masalah kepemimpinan merupakan masalah yang paling kontroversial adalam sejarah Islam.

Artikel ini membahas tentang pemahaman hadits kepemimpinan dari kaum Quraisy di era modern saat ini. Kajian ini merupakan kajian normatif kepustakaan di mana datanya berasal dari literatur, kitab, buku dan artikel yang berkaitan dengan hadits tersebut dan terkait dengan kepemimpinan. Sumber atau kajian dari referensi-refrensi dengan analisa konten dengan pendekatan bahasa, ilmu hadits, sejarah dan sosiologis.

Kajian dalam artikel ini dimulai dengan menampilkan hadits-hadits yang terkait dengan kepemimpinan dari suku Quraisy yang diambil dari berbagai kitab hadits yang mutabarah yang kemudian penulis melakukan takhrijj terhadap hadits-hadits tersebut untuk mengetahui kualitasnya. Selanjutnya penulis melakukan identifikasi kata kunci yang ada dalam hadits untuk dapat digunakan sebagai bahan menganalisa dan memahami hadits. Dari sinilah penulis melakukan kontekstualisasi pemahaman hadits-hadits tersebut. Dengan demikian haditshadits tentang kepimimpinan dari kalangan Quraisy ini tidak hanya menjadi "teks mati" yang tidak berlaku dan kompatibel dengan kondisi masyarakat modern.

\section{B. Hadits-Hadits terkait Kepemimpinan dari Quraisy}

Ada beberapa hadits yang terkait dengan kepemimpinan dari kaum Quraisy ini, yang paling popular adalah:

1. Riwayat dalam Șậih al-Bukhārì:

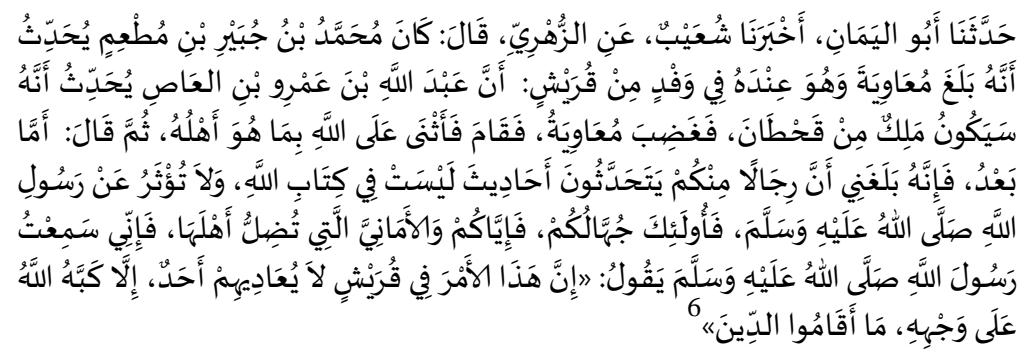

${ }^{6}$ Muhammad bin Ismail Abu Abdullah Al-Bukhari, Shohih Al-Bukhari, versi Digital Library, al-Maktabah al-Syamilah al-Isdar al-Tsani, IV/IX, 2005, Nomor Hadits 3500, hlm.179 dan Nomor Hadits 7139, 62. 
"Dari az-Zuhri berkata, bahwa Muhammad bin Jubair bin Muthim - yang kala itu bersama rombongan utusan dari Quraisy menyampaikan bahwa telah sampai berita kepada Muawiyah kalau Abdullah bin Amr bin Al-Ash menyampaikan bahwa ada datang seorang raja dari bangsa Qahthan. Maka marahlah Muawiyah. Beliau pun berdiri (berkhutbah) seraya memuji Allah dengan pujian yang layak bagi-Nya, kemudian beliau berkata, Amma Bad, sesungguhnya telah sampai kepadaku bahwa beberapa orang dari kalian menyampaikan sebuah pembicaraan yang tidak terdapat dalam Kitabullah, tidak pula diriwayatkan dari Rasulullah Shallallahu alaihi wa sallam. Mereka adalah orang-orang bodoh di antara kalian. Hati-hatilah kalian dari cerita-cerita yang bisa menyesatkan. Sesungguhnya aku mendengar Rasulullah Shallallahu alaihi wa sallam bersabda: "Sesungguhnya urusan ini (kekuasaan/khilafah) berada di tangan bangsa Quraisy. Tidaklah seorangpun yang menentang mereka (Quraisy) kecuali pasti Allah serert dia ke dalam Neraka. (Kejayaan itu) selama mereka (Quraisy) menegakkan agama".

2. Riwayat dalam Șaḥiḥ Muslim:

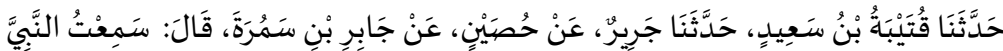

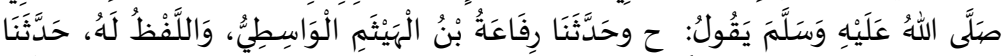

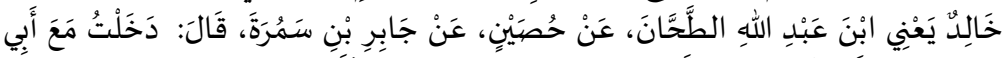

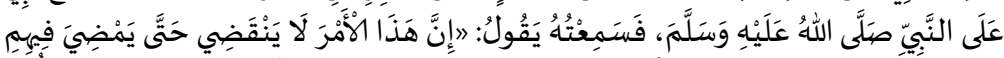

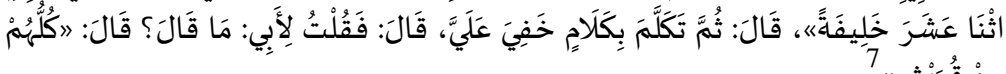

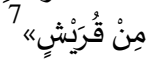

"Diriwayatkan dari Qutaibah bin Said, riwayat dari Jarir, dari Huṣain, Riwayat dari Jābir bin Samurah, ia berkata, aku mendengar Nabi Shallallahu alihi wa sallam bersabda: "Sesungguhnya pemerintahan ini tidak akan runtuh hingga kedua belas orang khalifah memerintah". Kemudian beliau mengucapkan kata-kata yang kurang jelas bagiku, Jabir berkata: "Lalu aku bertanya kepada ayahku, Apa yang dikatakan beliau?" ayahku menjawab: "(beliau mengatakan) Semuanya dari bangsa Quraisy”.

3. Riwayat dalam kitab Sunan Abu Daud:

${ }^{7}$ Muslim bin al-Hajjaj Abu al-Hasan al-Qusyairi al-Nisaburi Muslim, Shahih Muslim, versi Digital Library, al-Maktabah al-Syamilah al-Isdar alTsani, III dan IX, 2005, Nomor Hadits 1821, hlm. 1452 dan No.Hadits 3393, 3397, hlm. 333 dan 337. 


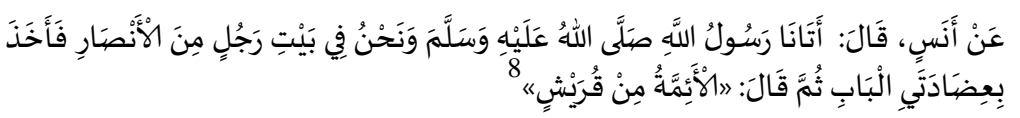

"Dari Anas ia berkata: Rasulullah Shallallahu alaihi wa sallam mendatangi kami yang kala itu sedang berada di salah satu rumah sahabat Anshor. Beliau sambil berpegangan pada tiang pintu (kusen) bersabda: Para pemimpin itu dari bangsa Quraisy”.

4. Riwayat dalam kitab Sunan al-Baihaqi:

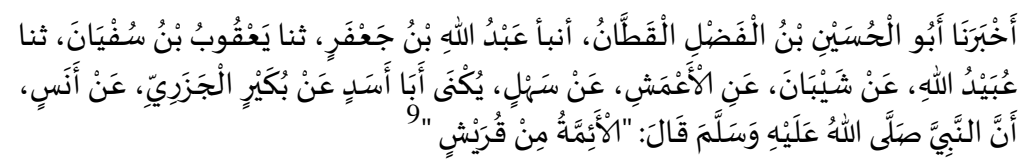

"Diriwayatkan dari Abu al-Hasan bin Faḍl al-Qațān, riwayat dari Abdullah bin Jafar dari Yaqūb bin Sufyan dari Abdullah dari Syaibān dari al-Amasy dari Sahl dari Anas bahwa sesungguhnya Nabi Muhammad saw. bersabda: Kepemimpinan (khilafah) itu dari suku Quraisy".

\section{Riwayat dalam kitab Sunan al-Nasāi:}

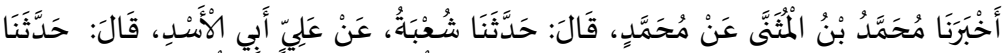

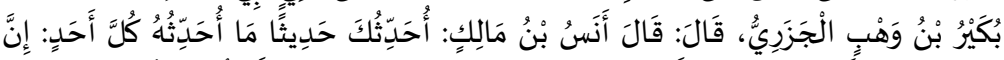

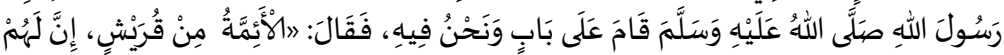

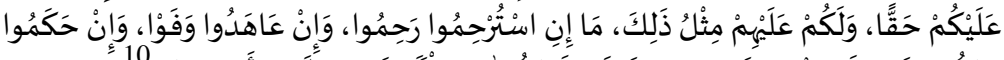

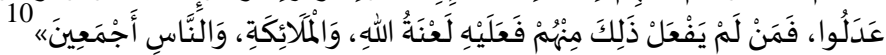

"Bukair bin Wahb Al-Jazari berkata, Anas bin Malik berkata kepadaku, Aku akan ceritakan kepadamu sebuah hadits yang tidak aku ceritakan kepada setiap orang, sesungguhnya Rasulullah saw. pernah berdiri di depan pintu, sedang kami ada di situ, beliau lalu bersabda: "Sesungguhnya para pemimpin itu dari Quraisy. Mereka punya hak yang harus kalian penuhi sebagaimana kalian juga mempunyai hak yang harus mereka penuhi. Jika mereka diminta untuk mengasihi, mereka akan mengasihi. Jika mereka berjanji,

${ }^{8}$ Sulaiman bin al-Asyats bin Syaddad bin Amr Al-Azadi, Sunan Abū Daud, versi Digital Library, al-Maktabah al-Syamilah al-Isdar al-Tsani, II, 2005, hlm. 163.

9 Abu Bakar Ahmad bni al-Husain bin Ali Al-Baihaqi, Sunan AlBaihaqi, versi Digital Library, al-Maktabah al-Syamilah al-Isdar al-Tsani, III, 2005, No. Hadits 5098, hlm. 172.

${ }^{10}$ Abu Abdurrahman Ahmad bin Syuaib Al-Nasai, Sunan Al-Nasai, versi Digital Library, al-Maktabah al-Syamilah al-Isdar al-Tsani, V, 2005, No. Hadits 5909, hlm. 405. 
mereka penuhi. Jika mereka menetapkan hukum, mereka berlaku adil. Siapa saja di antara mereka yang tidak berbuat seperti itu, mereka akan mendapatkan laknat Allah, Malaikat dan semua manusia".

6. Riwayat dalam kitab Musnad Imam Ahmad:

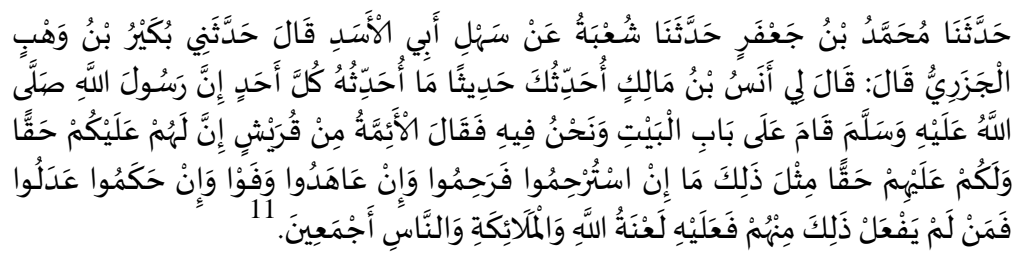

\section{Takhrij Hadits}

Dari beberapa hadits di atas, di sini penulis menampilkan tiga riwayat sebagai contoh, yaitu riwayat dari jalur Imām Baihaqī, Aḥmad bin Hanbal dan jalur al-Nasai:

11 Ahmad Bin Hanbal, Musnad Ahmad, versi Digital Library, alMaktabah al-Syamilah al-Isdar al-Tsani, XXIV, 2005, No. Hadits 11859, hlm. 405 . 


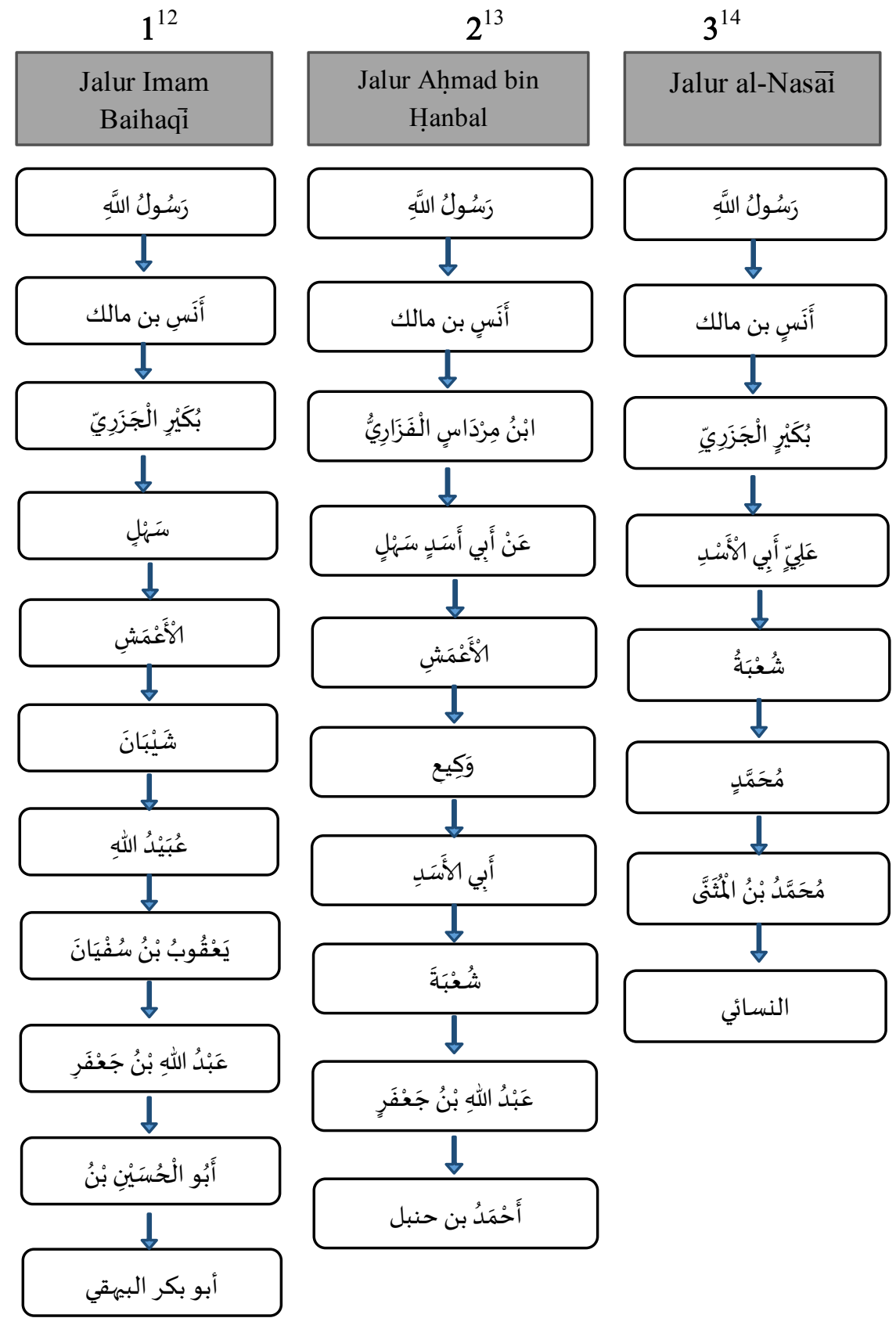

${ }^{12}$ Al-Baihaqi, Sunan Al-Baihaqi, No. Hadits 5098, hlm. 172.

${ }^{13}$ Ibn Hajr al-'Asqalani, Ittihaf al-Mahrah bi al-Fawaid al-Mubtakirah min Atrafi al-Asyrah, Jilid. 1 (Madinah: Majma' al-Mulk Fahd, 1994), hlm. 427.

${ }^{14}$ Al-Nasai, Sunan Al-Nasai, No.Hadits 5909, hlm. 405. 
Berdasarkan bagan di atas, ada enam jalur riwayat yang dapat penulis tampilkan terkait dengan kepemimpinan dari kaum Quraisy ini berdasarkan riwayat dari Ahmad bin Hanbal:

$$
\begin{aligned}
& \text { 1. قال أبو داود الطيالسي: ثنا سكين، ثنا سيار بن سلامة، سمع أبا برزة يرفعاه إلى النبي }
\end{aligned}
$$

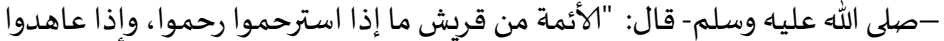

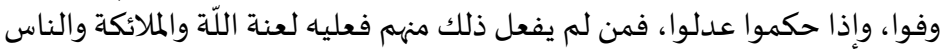

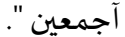

$$
\begin{aligned}
& \text { 2. رواه أبو بكر بن أبي شيبة: ثنا عفان، ثنا سكين... فذكره. }
\end{aligned}
$$

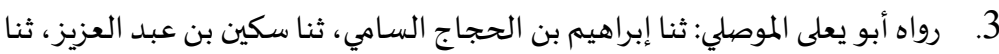

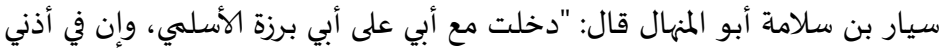

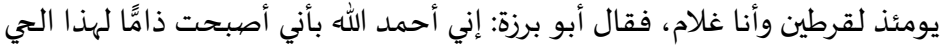

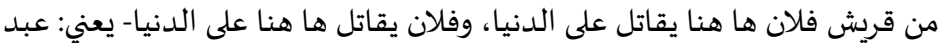

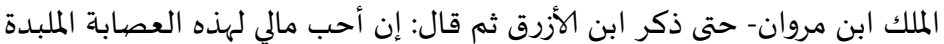

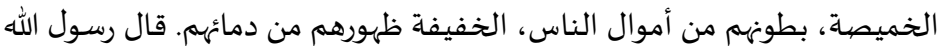

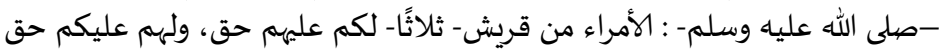

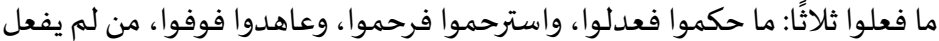

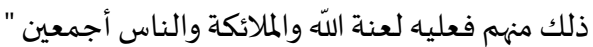

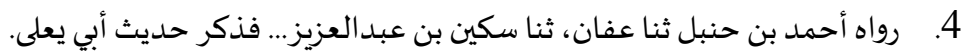

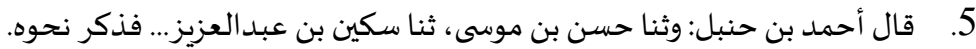

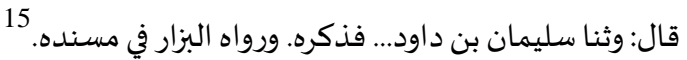

Berdasarkan penelusuran penulis, hadits yang terkait dengan kepemimpinan dari kaum Quraisy sebagaimana telah dipaparkan di atas, terutama riwayat imam Bukhārì dan Ahmad bin Hanbal, adalah șahịh dari sisi sanad dan matannya, serta tidak adanya unsur syadz dan cacat dalam hadits-hadits tersebut sehingga sudah bisa dijadikan landasan untuk menyatakan bahwa hadits tersebut dapat diterima (maqbūi). ${ }^{16}$ Hanya saja, dalam pengamalan hadits tersebut dalam konteks masyarakat modern perlu kontekstualisasi, sehingga spirit dan substansinya akan tetap berlaku dalam kehidupan sosial masyarakat.

15 Syihabuddin Ahmad bin Abi Bkr bin Ismail Al-Busiri, Ittihaf alKhiyarah al-Mahrah Bi Zawaid al-Masanid al-Asyrah, Jilid. 4 (Madinah: Dar al-Watan, 1999), hlm. 67.

${ }^{16}$ Muhammad Ajjaj al-Khatib, Usul al Hadis: Ulumuh wa Mustalahuh (Beirut: Dar Al-Fikr, 1989), hlm. 303. 


\section{Beberapa Kata Kunci untuk Memahami Hadits tentang Kepemimpinan dari Quraisy}

Terkait kajian hadits-hadits dengan tema kepemimpinan suku Quraisy, perlu ditegaskan di sini bahwa: "pertama, teks hadits dengan penggunaan lafadz al-Aimmah min Quraisy ada dalam kitab musnad Ahmad bin Hanbal yang berisi delapan riwayat. Kedua, teks hadits dengan menggunakan lafadz lain yaitu là yazālu termuat dalam tiga jalur periwayat hadits yaitu, Ahmad bin Hanbal, Muslim dan Bukhari. Ketiga, total periwayat dalam hadits ada 34 orang dan di antaranya ada tiga orang yang merupakan mukharrij. Keempat, dalam periwayatan hadits ini lafadz tahammul yang dipakai adalah dengan memakai kata Qala, sami'tu, sana, haddasana, akhbarana, 'an dan inna. Kelima, dalam penelusuran terdapat periwayat yang tidak disebut namanya secara jelas, yaitu pada jalur sanad al-Bukhari, sebutannya adalah Abu al-Yaman. Dalam kitab Tahdzib al-Tahdzib-nya al-Asqalani, beliau menyatakan bahwa sebutan tersebut adalah Al-Hakam bin Nafi al-Bahrani. Kemudian ada lafadz 'an abi dari riwayat Abd Allah ibn Umar yang terdapat pada tiga jalur sanad, al-Bukhari, Muslim dan Ibn Hanbal. Setelah dicek kembali ternyata penyebutan itu tertuju pada Muhammad bin Zayd Abd Allah bin Umar". ${ }^{17}$

Selanjutnya, ada beberapa kata kunci yang harus dipahami untuk mendapat pemahaman yang komprehensif dan kontekstual terhadap hadits-hadits dalam tema kepemimpinan dari bangsa Quraisy ini. Kata-kata kunci ini antara lain adalah:

\section{Al-Aimmah}

Al-aimmah adalah bentuk jamak dari kata imām yang berarti pemimpin. Kata al-aimmah dalam hadits ini berarti khalifah. ${ }^{18}$ Landasan pendapat ini adalah hadits riwayat Imam Muslim:

${ }^{17}$ Canra Krisna Jaya, "Kritik terhadap Pemahaman yang Menyatakan Bahwa Kepemimpinan Islam Harus Berasal dari Bani Quraisy," Religious: Jurnal Studi Agama-agama dan Lintas Budaya, Vol. 2, no. 2 (2018): hlm. 178179.

18 Iyad bin Musa bin Iyad bin Amr Al-Sabti, Ikmal al-Muallim bi Fawaid Muslim, Jilid. 6 (Dar al-Wafa, 1998), hlm. 215. 


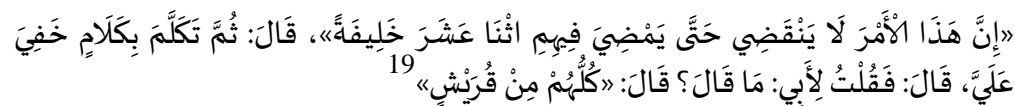
Khalifah secara Bahasa sebagimana dikemukakan Ibnu Manzūr adalah:

$$
\text { خلفه يخلفه صار خلفه. الذي يَستخلف مِمّن قبله، والخلافة الإمارة. } 20
$$

Secara terminologi khalifah diartikan pengganti, pembuat undang-undang, sebagai penegak peraturan agama dan aturan-aturan sosial. Jabatan pengganti Nabi Muhammad saw. yang tugasnya tidaklah berbeda, yakni menegakkan agama serta menggerakkan roda kepemimpinan dunia. ${ }^{21}$ Khalifah memerintah beberapa wilayah atau bahkan negara dengan satu hukum yang berlaku. ${ }^{22}$

\section{Quraisy}

Quraisy merupakan anak keturunan Nadar bin Kinanah. Ada perbedaan pendapat ulama mengenai penyebutan mereka dengan sebutan "Quraisy". Pendapat lain mengatakan bahwa asal muasal kata Quraisy yakni dari kata al-Qarsy yang memiliki arti berusaha dan mengumpulkan. Ada yang berpendapat bahwa sebutan ini berasal dari nama salah satu binatang laut yang sangat kuat (monster laut) pemakan binatang lainnya dan tiada tanding. Quraisy dengan tasgir merupakan bentuk penghormatan. ${ }^{23}$ Quraisy menjadi nama suku yang sangat terkenal di Makkah dan menjadi penjaga Kabah sebagai bangunan suci tempat berkumpulnya para dewa dan pusat ibadah orang-orang Arab. ${ }^{24}$ Ini merupakan makna Qurasiy dalam konteks yang sempit (mikro). Makna Quraisy secara lebih luas (makro) yaitu bangsa Arab, bila melihat konteks klasifikasi Arab dan Ajam.

${ }^{19}$ al-Nisaburi, Shahih Muslim, No. Hadits 1821, hlm. 1452, No. Hadits 3393, 3397, hlm. 333, 337.

${ }^{20}$ Ibnu Manzu, Lisan al-'Arab, versi Digital Library, al-Maktabah alSyamilah al-Isdar al-Tsani, 22, 2005, hlm. 169.

${ }^{21}$ Thoha, Muqaddimah Ibn Khaldun, hlm. 232-234.

${ }^{22}$ Al-Sabti, Ikmal al-Muallim bi Fawaid Muslim, hlm. 10.

${ }^{23}$ Muhammad bin Yusuf bin Ali bin Said Syamsuddin Al-Karamani, al-Kawakib al-Durari fi Syarh Sahih al-Bukhari, Jilid. XIV (Beirut: Dar Ihya alTurast al-Arabi, 1981), hlm. 115.

${ }^{24}$ Hitti, History of the Arabs, hlm. 142. 


\section{Berpedoman pada kitabullah dan sunnah Rasulullah}

Bila berpegang pada Kitab dan Sunnah dimaknai secara tekstual, maka pendapat di atas masih menutup kepemimpinan dari non-muslim. Namun, bila berpegang pada Kitab dan Sunnah dimaknai secara kontekstual dan substansial, seperti kepemimpinan yang sesuai dengan prinsip pokok dan moralitas al-Qur'an dan al-Sunnah yang memperjuangkan keadilan, kebenaran, kemaslahatan, keamanan, kenyamanan dan menghindari perilaku destrultif, maka pemaknaan ini cukup relevan dengan berbagai kondisi, situasi. Makna universal yang tidak mengenal sekat zaman dan lokus. Artinya prinsip ini compatible di mana pun dan kapan pun.

4. (إنحكموا عدلوا) Bersikap adil

Ibn Taimiyah menggolongkan keadilan ke dalam dua jenis, yakni syariyah dan aqliyah. Keadilan yang diperoleh melalui penerapan setiap hukum syariat disebut dengan keadilan syariyah. Sedangkan keadilan yang dapat dicapai melalui penerapan kaidah indera dan akal mencakup kebermanfaatan untuk hidup dan kehidupan manusia disebut dengan keadilan aqliyah. $^{25}$ Imamah (kepemimpinan) merupakan suatu badan yang mengawasi lembaga-lembaga lain dalam menjalankan tugasnya yang juga mensyaratkan keadilan. ${ }^{26}$

5. Menepati janji

Menepati janji merupakan bagian dari sikap amanah. Seorang pemimpin selain harus adil juga harus menepati janji-janjinya. Terlebih bila ia dipilih oleh masyarakt karena janji-janjinya sebelum menjadi pemimpin. Menepati janji merupakan hal yang sangat diperhatikan dalam Islam. Banyak ayat dan hadits yang terkait dengan penepatan janji dan konsekuensi bagi orang yang tidak menepati janji.

6. وإن استرحموا رحموا) Mengayomi

25 Ahmad bin Abd al-Halīm bin Abd as-Salām Ibnu Taymiyyah, alSiyasah al-Syariyyah fi Islah Rai wa Raiyyah (Beirut: Daar Al-Kutub Al'Ilmiyah, 1988), hlm. 121.

${ }^{26}$ Thoha, Muqaddimah Ibn Khaldun, hlm. 238. 
Seorang pemimpin harus memberikan perlindungan, keamanan dan kenyamanan kepada masyarakat yang dipimpinnya. Pemimpin harus melindungi dan menjamin hakhak masyarakat. Ia harus menciptakan perangkat dan infrastruktur yang memadai untuk memberikan perlindungan kepada masyarakat yang dipimpinnya. Pemimpin juga harus bersifat dan bersikap lemah lembut dan santun. ${ }^{27}$ Karena dari sinilah akan timbul rasa mengayomi.

\section{E. Memahami Substansi dan Konteks Hadits}

Untuk memahami hadits-hadits di atas, perlu pemaparan pendapat-pendapat ulama dalam kitab syarah hadits. Di sini penulis menampilkan beberapa pendapat ulama tersebut.

Berkaitan dengan kepemimpinan, dalam pemahaman fiqhul hadits, perhatian besar yang diberikan terhadap keharusan Quraisy menjadi syarat keturunan (nasab) dalam pengangkatan pemimpin (Imam/Khalifah) menimbulkan perdebatan yang alot di antara para ulama pada masa itu. Beberapa ulama menganggap bahwasanya ini merupakan sebuah keharusan dalam peng-akad-an khalifah, dan beberapa ulama menyatakan bahwa ini hanyalah sebuah keutamaan saja. Shaikh Abdul Wahab Khalaf dan alKhurbuṭli dalam kitabnya menolak kesahihan hadits tersebut. Mereka beranggapan bahwa hadits tersebut tidak jelas asalusulnya dalam syara dan tidak ada pula nash shahih yang menunjukkannya. ${ }^{28}$

Beberapa kelompok seperti Madzhab Ahlu Sunnah, Syiah, sebagian kelompok Mu'tazilah, dan sebagian besar kelompok Murjiah menganggap keturunan Quraisy sebagai keharusan dalam pengangkatan khalifah. ${ }^{29}$ Akan tetapi melihat asbāb al-wurūd yang ada, hadits ini muncul disebabkan adanya adu argumentasi di antara para imam dari Quraisy dan kaum Anshar dalam masalah imamah. Hal ini disaksikan oleh para sahabat dan akhirnya

${ }^{27}$ Thoha, hlm. 231.

28 Shaikh Abd al-Wahhab Khalaf, al-Siyasah al-Shariyyah, (alMatba'ah al-Salafiyyah, 2015), hlm. 28. Lihat juga al-Khurbutli, al-Islam wa alKhilafah, hlm. 59.

${ }^{29}$ Imam Ibn Hazm, "al-Afasl fi al-Milal wa al-Nihal", Jilid. IV (Beirut: Dar Al-Ma'rifah, 1404), hlm. 89. 
mereka menerima argumen dari para Imam Quraisy yang mana pada masa itu lebih piawai dibandingkan kaum Anshar.Dan inilah yang menyebabkan adanya persyaratan Quraisy dalam menjadi khalifah. $^{30}$

Kecakapan Ibnu Khaldun (1332 s.d. 1406 M) dalam menguraikan teks-teks keagamaan dalam bingkai cultural studies, membuat beberapa catatan yang ditulisnya menjadi menarik untuk diteliti, seperti halnya banyak dijumpai dalam magnum opus-nya, Muqaddimah. Dalam kerangka sosiologi, ia mengungkapkan bahwa ketentuan hadits Quraisy erat kaitannya dengan persoalan etnis yang sukar dicabut dari akar karakteristik kepemimpinan bangsa Arab saat itu.

Dalam tinjauan sejarah, dahulunya suku Jazirah Arab dikenal kaum yang tidak mempunyai daerah kekuasaan khusus dan hidup secara nomaden. Oleh karenanya, invasi dan penaklukan antara satu suku terhadap suku lain merupakan hal yang sudah biasa terjadi saat itu. Sehingga terbentuknya wilayah kekuasaan didasarkan atas kerja sama serta kesepakatan antar suku yang tinggal di wilayah yang sama. Di sisi lain, untuk mencegah adanya penaklukan oleh suku lainnya, dibentuklah suatu kemitraan politik yang biasanya dipegang oleh suku yang terkuat dan paling dihormati. Dalam hal ini suku Quraisy memegang peranan yang sangat penting di masyarakat Arab primitif dalam kontestasi politik. Menurut Khalil Abdul Karim (1997), label suku Quraisy sebagai suku yang mempunyai keberanian dan pengaruh yang kuat telah diceritakan secara runtut dalam sejarah. Hal ini diketahui dari penaklukan wilayah yang dilakukan oleh Qushay bin Kilab (w. 480 M), penaklukan pertama kali yang diteruskan oleh keturunannya yakni Abdu Manaf dan Abdul Muthalib. ${ }^{31}$

Berdasarkan hal tersebut, menurut Ibnu Khaldun sangatlah logis apabila nabi mengharuskan bahwa seorang pemimpin berasal dari suku Quraisy. Hal tersebut ditujukan agar seorang pemimpin dapat melindungi suku dari ancaman serta kekacauan ( $r a f u$ al-

30 Al-Mawardi, "Ahkam al-Sultaniyyah" (Mesir: Mustafa al-Babi alHalabi wa Awladuh, 1966), hlm. 5-6. Lihat: Abu al-Hasan al-Ashari, Maqalat al-Islamiyyin I: hlm. 41

${ }^{31}$ Ibn Khaldun, "Muqaddimah" (Beirut: Dar Al-Fikr, t.t.), hlm. 194. 
tanazu). Pemikiran ini didasari atas konsepsi penaklukan (conquest) yang memberikan inspirasi bagi terbentuknya teori konflik sebagai salah satu dari teori berdirinya suatu negara. Menurut Ibnu Khaldun, perlindungan atas wilayah teritorial dan menghindari adanya ancaman dari bangsa lain merupakan tujuan semata dari kekuasaan. Pendapat Ibnu Khaldun mengenai definisi negara tersebut berbeda halnya dengan pendapat yang dikemukakan oleh Aristoteles dalam teori integrasi. ${ }^{32}$

Permasalahan yang muncul dalam hal kepemimpinan yang terdapat padahadits ini adalah persyaratan imamah dari kalangan Quraisy. Menurut al-Șakāfi dari kalangan Hanafiyah, berkaitan syarat kepemimpinan dari Quraisy, kepemimpinan ada dua macam. Kepemimpinan besar (al-imāmah al-kubrā) dan kepemimpinan kecil (al-imāmah al-ṣgrā). Persyaratan dari kalangan kaum Quraisy hanya berlaku pada kepemimpinan besar, it upun tidak harus sayyid (keturunan nabi). ${ }^{33}$

Sekilas hadits tersebut memang terkesan rasialis dan nepotisme. ${ }^{34}$ Sepintas, orang-orang Quraisy harus memegang kepemimpinan, bahkan apabila ada yang meyakini bahwa kepemimpinan boleh dipegang oleh orang selain suku Quriasy, maka ia termasuk ke dalam kelompok orang sesat dan keluar dari golongan orang yang selamat. ${ }^{35}$ Konsep demikian didasarkan atas ayat-ayat yang berisi pujian terhadap kaum Muhajirin, hadits tentang kepemimpinan suku Quraisy, dan kesepakatan para sahabat saat itu tentang karakter kepemimpinan kaum Quraisy. Ibnu Khaldun pada akhirnya mengkritik secara besar-besaran konsep kepemimpinan demikian. Ia berpendapat bahwa konsep sebenarnya ialah bukan berarti suku Quraisy yang harus memegang suatu kepemimpinan, namun lebih pada model kepemimpinannya yang tegas, kuat, kharismatik, dan tangguh. Substansi mengenai kepemimpinan pada dasarnya bukan terdapat pada suku Quraisy, akan tetapi lebih mengarah pada karakteristik

${ }^{32}$ Ibn Khaldun, hlm. 194.

33 Muhammad Anwar Syah bin Mazam Syah al-Kasymiri Al-Hindi, Faid al-Bari Ala Sahih al-Bukhari, Jilid. VI (Beirut: Dar Al-Kutub Al-Ilmiyyah, 2005), hlm. 477.

${ }^{34}$ Al-Hindi, hlm. 477.

${ }^{35}$ Ibn Hazm, "al-Afasl fi al-Milal wa al-Nihal", hlm. 108. 
yang memungkinkan seseorang pantas untuk dijadikan sebagai pemimpin sama halnya dengan karakteristik suku Quraisy pada masa itu. ${ }^{36}$

Kemajuan suku Quraisy dan sifat dermawan pada masanya di dunia Arab memang sudah dikenal sejak dulu. Hal ini lantaran mereka telah memiliki suatu koneksi untuk melakukan perjalanan jauh dalam rangka berdagang, ${ }^{37}$ hal ini juga didukung dengan pengetahuan mereka mengenai daerah-daerah di sekitarnya dan administrasi birokrasi masa itu. Hal tersebut dikarenakan pada saat itu mereka akan berinteraksi dengan raja-raja atau para pemuka kerajaan. Di luar karakteristik yang telah dijelaskan dalam hadits di atas, suku Quraisy juga memiliki keunggulan dalam hal berafiliasi, pergerakan massa yang terstruktur, ahli ekonomi yang handal, suku yang mayoritas, serta kesantunannya dalam birokrat.

Al-Tibbi mencatat bahwa kepemimpinan kalangan Quraisy selama sesuai dengan ajaran agama tidak ada seorang pun yang menentangnya. Orang Quraisy berusaha menegakkan ajaran dan syariat Islam. Namun demikian, bila mereka melupakan dan melenceng dari ajaran agama maka dihinakan oleh Allah. ${ }^{38}$

Adapaun maksud dari Imam dua belas seluruhnya dari kalangan Quraisy adalah golongan mereka yang adil. Kalangan Quraisy berhak menyandang kekhalifahan pada arti hakikat, dan tidak selalu bermakna kekuasaan, meskipun mereka juga mampu memegang kekuasaan. Hanya saja makna yang ada dalam kata Quraisy ini maksudnya adalah kaum muslimin. Penggunaan kata Quraisy adalah sebagai majaz. ${ }^{39}$

Berdasarkan paparan ini, maka konteks dan substansi hadits terkait dengan kepemimpinan ini adalah "adil", tidak terpaku pada suku atau golongan tertentu, akan tetapi terpaku

${ }^{36}$ Yusuf Al-Qardhawi, "Kayfa Nataamal ma'a al-Sunnah" (Cairo: Dar al-Syuruq, 2000), hlm. 24.

37 al-Mubarakfuri, "al-Rahiq al-Makhtum", hlm. 60.

38 Syarfuddin Al-Husain bin Abdullah Al-Tibbi, al-Kasysyaf An Haqaiq al-Sunan, Jilid. XII (Riyad: Maktabah Musthafa al-Baz, 1997), hlm. 3831. Baca juga al-Husain bin Mahmud bin al-Hasan Mazaruddin al-Zaidani alKufi, Al-Mafatih fi Syarh al-Masabih, Jilid. VI, (Kuwait: Dar al-Nawadir, 2012), hlm. 279

${ }^{39}$ Al-Tibbi, hlm. 3831. 
pada moralitas dan perilaku. Selama bisa bersikap adil, maka ini yang lebih berhak dan diprioritaskan untuk menjadi pemimpin.

Ibnu Baṭal, Niẓām dan Darar dalam catatan penjelasan hadits tentang kepemimpinan dari Qurasy mengatakan bahwa "Quraisy" bukanlah syarat utama dalam kepemimpinan. Siapa saja boleh menjadi pemimpin dengan syarat berpegang pada kitabullah dan Sunnah nabi-Nya, artinya boleh dari kalangan Arab dan non-Arab. ${ }^{40}$ Meskipun pendapat ini lebih terbuka dibanding pendapat ulama yang mensyaratkan kepemimpinan harus dari kalangan Quraisy, namun pada dasarnya, pendapat tersebut masih saja eksklusif, karena hanya berlaku bagi umat Islam. Pendapat ini cukup beralasan, apalagi bila dikaitkan dengan hadits lain, misalnya hadits riwayat Bukāri dan Muslim yang bila dipahami bahwa ada kemungkinan besar pemimpin berasal dari luar Quraisy, yaitu dari Qahțān (salah satu nama wilayah di Syam, yaitu sebuah daerah yang terletak di Timur laut Mediterania, Barat sungai Efrat atau Gurun Arab dan sebelah Selatan pegunungan Turus). Riwayat ini dari Abu Hurairah:

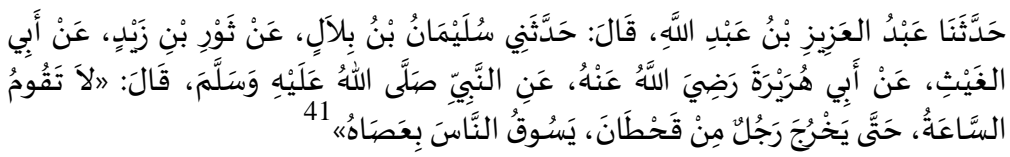

Muawiyah mengingkari hadits riwayat Abū Hurairah di atas.Sikap Muawiyah tersebut cukup wajar. Selain ia mempunyai agenda politik, ia hanya berpegang pada zhahir hadits " إِنَّ هَذَا الأمَرَ فِيف

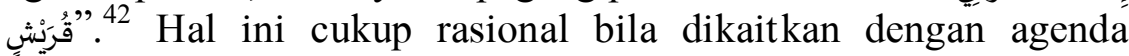
politik Muawiyah.

Selain hadits ini, ada hadits lain yang bisa dijadikan argumen bahwa pada dasarnya kepemimpinan tidak harus selalu dari suku Qurasy, riwayat Abu Daud dan Baihaqi:

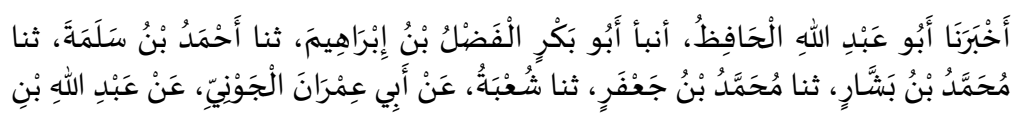

${ }^{40}$ Abu al-Hasan bin Khalaf bin Abdul Mulk Ibnu Batal, Syarah alBukhari, versi Digital Library, al-Maktabah al-Syamilah al-Isdar al-Tsani, XV, 2005, hlm. 220.

${ }^{41}$ Al-Bukhari, Shohih Al-Bukhari, No. Hadits 7117, hlm. 58.

${ }^{42}$ Ibnu al-Mulqin Sirajuddin Abu Hafas Umar bin Ali bin Ahmad alSyafii al-Misri Sirajuddin, al-Taudih li Syarh al-Jami al-Sahih, Jilid. XX (Damaskus: Dar Al-Nawadir, 2008), hlm. 30. 


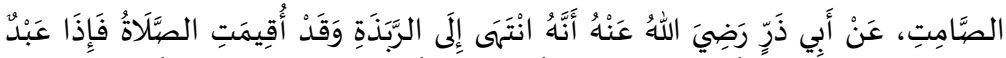

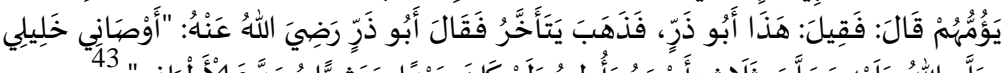

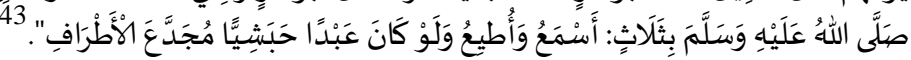

Apakah ada pertentangan (tanāqud) antara hadits Muawiyah dan Abū Hurairah? Jelas tidak, karena ada persyaratan "menegakkan agama" dalam hadits Muawiyah, sedang al-Qahțānī (Abū al-Yaman) bila pemimpin Quraisy tidak menegakkan agama. ${ }^{44}$ Bisa jadi ini menunjukkan kepemimpinan di akhir zaman. Apa yang diungkapkan Muawiyah memang berdasarkan faktatentang hak Quraisy terhadap kekhilafahan. ${ }^{45}$

Kepemimpinan adalah masalah politik yang tidak akan lepas dari perilaku politis. ${ }^{46}$ Berdasarkan hal ini, maka pernyataan Muawiyah pada hadits ini tidak lepas dari nuansa politik. Sejarah pun membuktikan bahwa Muawiyah mengambil "kursi kekhalifahan" dari Ali juga dengan cara yang sangat politis, bahkan sampai terjadi perang siffin. ${ }^{47}$

Hamzah Muhammad Qasim memberi catatan terhadap hadits kepemimpinan dari Quraisy yang diriwayatkan imam Bukhāri, pertama, khilafah menjadi hak syar'i yang dimiliki oleh kaum Quraisy, selama mereka berpegang pada kitab Allah dan menegakkan syariat. Apabila mereka mengikari dan berpaling dari kitab dan Sunnah, melenceng dari kebenaran dan keadilan maka

${ }^{43}$ Al-Azadi, Sunan Abū Daud, No. Hadits 4607, hlm. 200. al-Baihaqi, Sunan Al-Baihaqi, No. Hadits 5119, hlm. 125

${ }^{44}$ Muhammad bin Abu Bakr bin Umar bin Abi Bakr bin Muhammad al-Makhzumi al-Qarsyi, Masabih Al-Jami, Jilid. VII (Suriya: Dar al-Nawadir, 2009), hlm. 185; Syamsuddin al-Birmawi, Al-Lami al-Sabih Bi Syarh al-Jami al-Sahih, Jilid. XVII (Suriya: Dar al-Nawadir, 2012), hlm. 84.

45 Zakariya bin Muhammad bin Ahmad bin Zakariya Al-Ansari, Minhah al-Bari Bi Syarh Sahih al-Bukhari, Jilid. VI (Riyad: Maktabah alRusyd, 2005), hlm. 578.

${ }^{46}$ Baca Michael Brecher, Political Leadership and Charisma: Nehru, Ben-Gurion, and Other 20th Century Political Leaders: Intellectual Odyssey I (Erscheinungsort nicht ermittelbar: Palgrave Macmillan, 2016); Joseph Masciulli, Mikhail A Molchanov, dan W Andy Knight, "Political Leadership in Context," 2009, hlm. 26.

${ }^{47}$ Perang Siffin (Mei-Juli 657 Masehi) Terjadi Semasa Zaman Fitnah Besar Atau Perang Saudara Pertama Orang Islam Dengan Pertempuran Utama Terjadi Dari Tanggal 26-28 Juli. Pertempuran Ini Terjadi Di Antara Dua Kubu Yaitu, Muawiyah Bin Abu Sufyan Dan Ali Bin Abi Talib Di Tebing Sungai Furat Yang Kini Terletak Di Syria (Syam) Pada 1 Shafar Tahun 37 Hijriah. 
hak tersebut hilang dari mereka dan berpindah kepada yang lain. Karena kata kunci pada hadits ini adalah menegakkan agama. Kedua, hadits ini menunjukkan keistimewaan luar biasa yang dimiliki oleh suku Quraisy, yaitu hak mereka untuk memegang tongkat kekhilafahan, selama mereka menegakkan agama dan mengikuti sunah Rasulullah. ${ }^{48}$

\section{F. Kesimpulan}

Pemahaman terhadap suatu teks sumber ajaran Islam harus dilakukan secara komprehensif dengan berbagai pendekatan dan disiplin ilmu. Tidak cukup hanya dengan satu bidang ilmu saja, misalnya ilmu hadits, akan tetapi perlu ilmu lain seperti ilmu bahasa, sejarah, sosiologi, bahkan ilmu politik. Hal ini agar mendapatkan pemahaman teks secara utuh, komprehensif dan integratif. Seperti halnya memahami hadits tentang kepemimpinan dari suku Quraisy yang secara tekstual memang menyatakan bahwa kepemimpinan dari kaum Quraisy. Hanya saja untuk mengimplementasikannya perlu pemahaman yang komprehensif. Teks hadits menyatakan kepemimpinan dari suku Quraisy, sementara sekarang ini persebaran Islam sudah menjuru ke seluruh belahan dunia dan sistem kepemimpinan sudah berkembang sesuai kondisi sosio-kultural dan sosial masyarakat. Selain itu, di sisi lain hadits atau al-Sunnah adalah sebagai sumber ajaran Islam kedua setelah al-Qur'an harus selalu kompitabel dengan semua kondisi zaman dan lokus. Sehingga memahami hadits secara kontekstual akan membawa sepirit dan substansi hadits-hadits tentang kepemimpinan dari suku Quraisy harus diamalkan. Karena di dalamnya ada maqasid syariah ah yang harus selalu dijalankan seperti keadilan, kebenaran, dan pengayoman.

48 Hahmazah Muhammad Qasim, Manar al-Qari Syarh Mukhtasar Sahih al-Bukhari, Jilid. IV (Damaskus: Maktabah Dar al-Bayan, 1990), hlm. 230. 


\section{Daftar Pustaka}

Abu Daud, Sulaimān bin al-Asyats bin Syaddād bin Amr alAzadi. Sunan Abì Daud. Digital Library, al-Maktabah alSyāmilah al-Iṣdār al-Tṣānī, 2005.

Ahmad Bin Hanbal. Musnad Ahmad (versi Digital Library). AlMaktabah al-Syamilah al-Isdar al-Tsani. XXIV, 2005.

Ajjaj al-Khatib, Muhammad. Usul al Hadis: Ulumuh wa Mustalahuh. Beirut: Dar Al-Fikr, 1989.

Al-Azadi, Sulaiman bin al-Asyats bin Syaddad bin Amr. Sunan $A b \bar{u}$ Daud (versi Digital Library). Al-Maktabah alSyamilah al-Isdar al-Tsani. II, 2005.

Al-Baihaqi, Abu Bakar Ahmad bni al-Husain bin Ali. Sunan AlBaihaqi (versi Digital Library). Al-Maktabah al-Syamilah al-Isdar al-Tsani. III, 2005.

Al-Bukhari, Muhammad bin Ismail Abu Abdullah. Shohih AlBukhari (versi Digital Library,). Al-Maktabah al-Syamilah al-Isdar al-Tsani. IV/IX, 2005.

Al-Busiri, Syihabuddin Ahmad bin Abi Bkr bin Ismail. Ittihaf alKhiyarah al-Mahrah Bi Zawaid al-Masanid al-Asyrah. Jilid. 4. Madinah: Dar al-Watan, 1999.

Al-Hindi, Muhammad Anwar Syah bin Mazam Syah al-Kasymiri. Faid al-Bari Ala Sahih al-Bukhari. Jilid. VI. Beirut: Dar Al-Kutub Al-Ilmiyyah, 2005.

Al-Karamani, Muhammad bin Yusuf bin Ali bin Said Syamsuddin. al-Kawakib al-Durari fi Syarh Sahih alBukhari. Jilid. XIV. Beirut: Dar Ihya al-Turast al-Arabi, 1981.

Al-Mawardi. "Ahkam al-Sultaniyyah". Mesir: Mustafa al-Babi alHalabi wa Awladuh, 1966.

Al-Nasai, Abu Abdurrahman Ahmad bin Syuaib. Sunan Al-Nasai (versi Digital Library). Al-Maktabah al-Syamilah al-Isdar al-Tsani. V, 2005.

Al-Qardhawi, Yusuf. "Kayfa Nataamal ma'a al-Sunnah". Cairo: Dar al-Syuruq, 2000. 
Al-Sabti, Iyad bin Musa bin Iyad bin Amr. Ikmal al-Muallim bi Fawaid Muslim. Jilid. 6. Dar al-Wafa, 1998.

Al-Tibbi, Syarfuddin Al-Husain bin Abdullah. al-Kasysyaf An Haqaiq al-Sunan. Jilid. XII. Riyad: Maktabah Musthafa alBaz, 1997.

Asqalani, Ibn Hajr al-'. Ittihaf al-Mahrah bi al-Fawaid alMubtakirah min Atrafi al-Asyrah. Jilid. 1. Madinah: Majma' al-Mulk Fahd, 1994.

Baihaqi, Abū Bakar Aḥmad bni al-Ḥusain bin Ali al-. Sunan alBaihaqi. Digital Library, al-Maktabah al-Syāmilah al-Iṣdār al-Tsāni, 2005.

Birmāwī, Syamsuddin al-. al-Lāmi al-Ṣabịh bi Syarh al-Jāmi alSahịh. Suriya: Dār al-Nawādir, 2012.

Brecher, Michael. Political Leadership and Charisma: Nehru, BenGurion, and Other 20th Century Political Leaders: Intellectual Odyssey I. Erscheinungsort nicht ermittelbar: Palgrave Macmillan, 2016.

DK Pub. Leadership: Inspiring, Empowering, Supporting. DK Pub, 2015.

Hitti, Philip Khuri. History of the Arabs. Jakarta: Serambi Ilmu Semesta, 2005.

Ibn Hazm, Imam. "al-Afasl fi al-Milal wa al-Nihal". Jilid. IV. Beirut: Dar Al-Ma'rifah, 1404.

Ibn Khaldun. "Muqaddimah". Beirut: Dar Al-Fikr, t.t.

Ibnu Batal, Abu al-Hasan bin Khalaf bin Abdul Mulk. Syarah alBukhari (versi Digital Library). Al-Maktabah al-Syamilah al-Isdar al-Tsani. XV, 2005.

Ibnu Manzu. Lisan al-'Arab (versi Digital Library). Al-Maktabah al-Syamilah al-Isdar al-Tsani. 22, 2005.

Ibnu Taymiyyah, Ahmad bin Abd al-Halīm bin Abd as-Salām. alSiyasah al-Syariyyah fi Islah Rai wa Raiyyah. Beirut: Daar Al-Kutub Al-'Ilmiyah, 1988.

Krisna Jaya, Canra. "Kritik terhadap Pemahaman yang Menyatakan Bahwa Kepemimpinan Islam Harus Berasal dari Bani Quraisy.” Religious: Jurnal Studi Agama-agama dan Lintas Budaya, Vol. 2, no. 2 (2018). 
Masciulli, Joseph, Mikhail A Molchanov, dan W Andy Knight. "Political Leadership in Context," 2009, 26.

Meffert, Jürgen, dan Anand Swaminathan. "Leadership And The Urgency For Digital Transformation." Leader to Leader 2018, no. 88 (Maret 2018): 44-49. https://doi.org/10.1002/lt1.20357.

Mubarakfuri, Safiy al-Rahman al-. "al-Rahiq al-Makhtum". Riyad: Makhtabah Dar al-Salam, 1994.

Muhammad Qasim, Hahmazah. Manar al-Qari Syarh Mukhtasar Sahih al-Bukhari. Jilid. IV. Damaskus: Maktabah Dar alBayan, 1990.

Nisaburi, Muslim bin al-Hajjaj Abu al-Hasan al-Qusyairi al-. Shahih Muslim (versi Digital Library,). Al-Maktabah alSyamilah al-Isdar al-Tsani. III dan IX, 2005.

Qarsyī, Muhammad bin Abū Bakr bin Umar bin Abì Bakr bin Muḥammad al-Makhzūmì al-. Mașābiḥ al-Jāmi. Suriya: Dār al-Nawādir, 2009.

Sirajuddin, Ibnu al-Mulqin Sirajuddin Abu Hafas Umar bin Ali bin Ahmad al-Syafii al-Misri. al-Taudih li Syarh al-Jami al-Sahih. Jilid. XX. Damaskus: Dar Al-Nawadir, 2008.

Thoha, Ahmadie, trans. oleh. Muqaddimah Ibn Khaldun. Jakarta: Pustaka Firdaus, 2000.

Zakariya Al-Ansari, Zakariya bin Muhammad bin Ahmad bin. Minhah al-Bari Bi Syarh Sahih al-Bukhari. Jilid. VI. Riyad: Maktabah al-Rusyd, 2005. 